\title{
An Early Calcium Loading during Cherry Tree Dormancy Improves Fruit Quality Features at Harvest
}

\author{
Michail Michailidis ${ }^{1}\left(\mathbb{D}\right.$, Chrysanthi Polychroniadou ${ }^{1}$, Maria-Anastasia Kosmidou ${ }^{1}$, Dafni Petraki-Katsoulaki ${ }^{1}$, \\ Evangelos Karagiannis ${ }^{1}$ (D) , Athanassios Molassiotis ${ }^{1}$ and Georgia Tanou ${ }^{2, *}$ \\ 1 Laboratory of Pomology, School of Agriculture, Aristotle University of Thessaloniki, 57001 Thermi, Greece; \\ msmichai@agro.auth.gr (M.M.); polychry@agro.auth.gr (C.P.); mariaan175@gmail.com (M.-A.K.); \\ dafnipet@outlook.com (D.P.-K.); karagiee@agro.auth.gr (E.K.); amolasio@agro.auth.gr (A.M.) \\ 2 Institute of Soil and Water Resources, ELGO-DEMETER, 57001 Thessaloniki, Greece \\ * Correspondence: gtanou@swri.gr
}

check for

updates

Citation: Michailidis, M.; Polychroniadou, C.; Kosmidou, M.-A.; Petraki-Katsoulaki, D.; Karagiannis, E.; Molassiotis, A.; Tanou, G. An Early Calcium Loading during Cherry Tree Dormancy Improves Fruit Quality Features at Harvest. Horticulturae 2021, 7, 135. https://doi.org/10.3390/

horticulturae7060135

Academic Editor: Esmaeil Fallahi

Received: 14 May 2021

Accepted: 4 June 2021

Published: 6 June 2021

Publisher's Note: MDPI stays neutral with regard to jurisdictional claims in published maps and institutional affiliations.

Copyright: (c) 2021 by the authors. Licensee MDPI, Basel, Switzerland. This article is an open access article distributed under the terms and conditions of the Creative Commons Attribution (CC BY) license (https:/ / creativecommons.org/licenses/by/ $4.0 /)$.

\begin{abstract}
The possible role of an early calcium application via sprays $\left(0.25,0.5\right.$ and $\left.1 \mathrm{M} \mathrm{CaCl}_{2}\right)$ on dormant buds to improve sweet cherry (cv. Ferrovia) fruit quality at harvest was investigated. Fruit quality characteristics were also investigated in response to the age of spurs, the ripening stage, and their interactions. Results indicate that calcium enters the dormant flower buds and the phloem but not to the dormant vegetative buds. At harvest, the levels of $\mathrm{Zn}, \mathrm{Mn}$, and $\mathrm{Cu}$ were declined in fruits by increasing $\mathrm{CaCl}_{2}$ doses of sprays. Fruit respiratory activity was higher and on-tree fruit cracking was lower in red-colour (unripe) cherries as well as in fruit that was produced by 2-year-old short spurs or by Ca-treated buds. Differences in the sweet cherry skin metabolic profiles were identified. Fruit produced from Ca-exposed spurs exhibited lower levels of ribose and other cell-wall-related sugars and higher sucrose, maltose, and quininic acid levels. Nutrient shift was increased in red cherries, while anthocyanins were boosted in the black ones. PCA analysis was performed between the high dose of calcium spray and a control for mineral element content and cherry quality traits. This study illustrates that the high dose of calcium application during bud dormancy can effectively improve sweet cherry fruit characteristics, in terms of calcium content, cracking incidence, and fruit set. Overall, the present study contributes to a better understanding of the impact of calcium nutrition in fruit crops, which will provide references for alternative nutrient management and quality control in sweet cherry production.
\end{abstract}

Keywords: bud dormancy; calcium; cracking; fruit nutrition; fruit quality; skin polar metabolites

\section{Introduction}

Sweet cherry (Prunus avium L.) is a highly demanded fruit, as it is the earliest stone fruit to ripen and because of its great consumer acceptance [1]. Its nutritional and commercial value gives the sweet cherry a great economic importance in more than forty temperate climate countries worldwide where environmental factors are favourable for its growth [2]. The quality of the sweet cherry fruit is highly affected by the environmental conditions, since excessive rainfall before and during the harvest can lead to the fruit cracking [3]. Although the mechanism that leads to cherry cracking remains unclear [4], cracking is currently assumed to be the result of a net influx of water into the fruit, causing an increase in fruit volume and surface area, resulting in a strained fruit skin, which eventually ruptures [5].

Calcium is a key mineral for most plant organs and tissues, particularly for fruit. The range of critical physiological functions affected by calcium is diverse and includes the signal transduction as a secondary messenger, the control of gene expression and protein, the maintenance and regulation of membrane permeability, and the cross-linking and structural reinforcement of cell wall constituents [6]. In fruit, including sweet cherries, high calcium has been reported to increase fruit firmness, reduce rain cracking susceptibility, 
decrease the incidence of rotting, and maintain colour and turgidity of pedicels [5]. Moreover, the low mobility of calcium in the xylem (it is not transported in the phloem) poses serious problems to ensure the distribution of this element to the fruit through calcium application in the soil. In addition, calcium taken up from the soil solution is transported in the xylem stream predominately to the leaves due to their high transpiration [7]. Subsequently, the treatment of aerial plant parts with calcium sprays is used to prevent fruit calcium deficiency or to improve fruit quality. The penetration of calcium into fruit likely occurs through the stomata on the fruit surface. However, penetration rates have been shown to vary with cultivar, application method, and formulation of calcium used [8]. Calcium supplementation is not always effective; in some studies, in-season foliar calcium applications were found beneficial while in others there was no significant effect, such as in blueberries and peaches $[9,10]$. In addition to this, there are limitations regarding the calcium concentration of the foliar solution due to leaf injury and defoliation caused when high calcium doses are applied $[9,11]$. An alternative strategy to foliage calcium spray could therefore be calcium sprays during tree dormancy, such as those performed in other mineral-element-based applications, including those of zinc and copper [12,13].

Considering the importance of calcium in the quality of sweet cherry, the objective of this study was to determine if calcium sprays applied during sweet cherry tree dormancy could affect the overall sweet cherry fruit quality at harvest. Three main factors, namely dosage of calcium sprays, age of short spurs sprayed, and harvest at two fruit ripening stages, as well as their interaction in response to early calcium application, were evaluated. Additionally, skin metabolic characteristics were assessed and linked to cracking incidence to gain insight into the physiological background of calcium-affected cracking behaviour.

\section{Materials and Methods}

\subsection{Tree Processing and Fruit Sampling}

The experiment was conducted in an experimental sweet cherry orchard of cv. Ferrovia (Prunus avium L.). The orchard consisted of 10 -year-old trees, planted at $5 \times 5 \mathrm{~m}$ spacing between rows and along the row, grafted onto MaxMa 14 rootstock and trained in open vases. The application of calcium $\left(\mathrm{CaCl}_{2}{ }^{*} \mathrm{H}_{2} \mathrm{O}, \mathrm{ACS}\right.$ reagent, $\geq 99 \%$ Sigma-Aldrich $+0.01 \%$ TWEEN 20 Sigma-Aldrich) was performed in 8 sweet cherry trees via spray $(0,0.25,0.5$ and $1 \mathrm{M} \mathrm{CaCl}_{2}$ ) on either one- or two-year-old short spurs at dormancy stage, specifically two weeks prior to buds burst (Figure S1). At each tree, a quarter of the canopy was sprayed for each calcium treatment. One week after external calcium application, phloem tissue, flowers, and vegetative buds were tested for internal calcium and other mineral element content. In addition, fruit set (\%) was determined 40 days after full blossom (DAFB). Cherry fruits were harvested at two different ripening stages, namely red and black skin colour, at 81 DAFB. Accordingly, four calcium treatments $\left(0,0.25,0.5\right.$, and $\left.1 \mathrm{M} \mathrm{CaCl}_{2}\right)$ and two ripening stages (red and black skin colour) in two ages of short spurs ( 1 and 2 years old) were studied, as well as their interacting effects. A schematic representation of the experimental procedure is provided in Figure 1. 


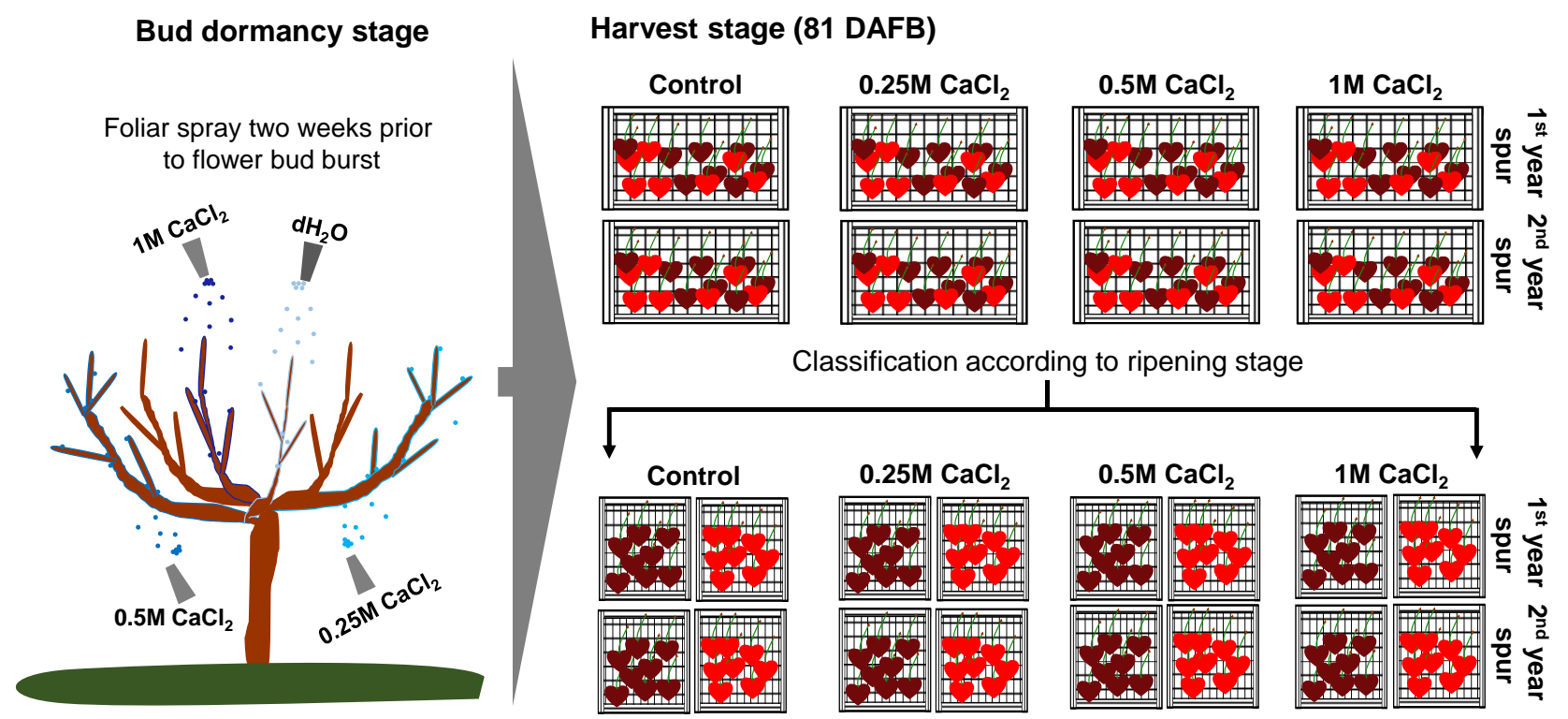

Figure 1. Schematic representation of the experiment procedure. Calcium treatments $\left(0,0.25,0.5\right.$, and $\left.1 \mathrm{M} \mathrm{CaCl} 2 * 2 \mathrm{H}_{2} \mathrm{O}\right)$ were applied in sweet cherry (cv. Ferrovia) trees at bud dormancy stage, specifically two weeks prior to flower bud burst. Sweet cherry fruits were harvested and grouped based on calcium treatments, the ages of short spurs (1- and 2-year-old spurs) and the ripening stage (red and black colour); afterwards, samples were analysed for nutrient content, quality attributes, and skin metabolites.

The number of cracked fruits was visually recorded at harvest, while the noncracked fruits just after harvest were assessed for cracking using two in vivo estimation methods. Fruits were transferred to the laboratory, classified according to their ripening stage (red and black skin colour), and several physiological traits were evaluated (Figure 1).

\subsection{Fruit Set}

The fruit set (\%) was determined in the individual trees following calcium treatments, and the two types of spurs ( 1 and 2 years old) using three replicates per condition (e.g., control/tree 1/1-year-old spur). At full blossom, the flowers were initially marked and measured for each condition in triplicate (three branches). Thereafter, by 40 DAFB, the remaining fruits were measured in each marked branch on the tree, and the results were expressed as percentage of fruit set $(\%)$.

\subsection{Fruit Quality Characteristics}

\subsubsection{Skin Cracking Assessment}

Sweet cherry skin cracking incidence was evaluated on tree at harvest (81 DAFB). Thereafter, the non-skin-splitted cherries were assessed for their cracking potential using Christensen and Waterfall methods, as previously described [14].

Skin cracking in the orchard was measured in the experimental fruits (calcium treatment/spur types/ripening stages) in four replicates per condition. Each replicate consisted of 50 fruits for which the incidence of skin cracking was recorded, and the results were expressed as a percentage (\%). Similarly, the skin cracking was assessed using two in vivo methods (calcium treatment/spur types/ripening stages) on the remaining intact fruits using three replicates per condition. Skin cracking in the orchard was determined due to rain precipitation during fruit development and, in particular, the days near harvest (Figure S1).

To evaluate the in vivo sweet cherry cracking, fruits ( 3 replicates $\times 25$ fruits) just after harvest were weighed and immersed in distilled water based on the modified 'Christensen method' [15], as previously described in detail [14]. The results were expressed as a percentage of cracking susceptibility (\%) by the equation $\left[\sum_{i=1}^{6}(7-\mathrm{i}) \times\right.$ cracked fruits in i hour $) / 6$ 
$\times$ total fruits] $\times 100$. In addition to this assay, another batch of fruits (3 replicates $\times$ 25 fruits) was evaluated for skin cracking using the currently established 'Waterfall method', in which fruits are continuously wetted under controlled conditions [14]. The results were expressed as a percentage of skin cracking susceptibility (\%) by the equation $\left\{\left[\sum_{i=1}^{4}(13-\mathrm{i}) \times\right.\right.$ cracked fruits in i hour $)+\sum_{n=3}^{6}(13-2 \times \mathrm{n}) \times$ cracked fruits in $(2 \times \mathrm{n})$ hour) $/ 12 \times$ total fruits $\} \times 100$.

\subsubsection{Fruit Water Absorption}

Sweet cherry fruits were weighted before and just following both cracking assays (Christensen and Waterfall methods) after the removal of surface water by centrifugation and airflow for $1 \mathrm{~min}$. The results were expressed as a percentage (\%) of fruit water absorption.

\subsubsection{Fruit Weight}

Weight (gr) in three batches of ten fruits per condition (calcium treatment/spurs types/ripening stages) of the whole fruit and its individual parts (stem, core, and flesh) were determined. The results were expressed as the ratio of flesh weight to the whole fruit weight (\%). Furthermore, dry weight in three batches of ten fruits per condition (calcium treatment/spurs types/ripening stages) was determined, following fruits drying in an oven at $65{ }^{\circ} \mathrm{C}$ for three days. The results are expressed as a percentage (\%).

\subsubsection{Fruit Ripening Traits}

Three batches of ten fruits from each condition (calcium treatment/spurs types/ripening stages) were juiced (core excluded) in a mechanical blender, then centrifuged, and the total soluble solids (TSS, \% Brix) were determined at the supernatant using an electronic refractometer (model Atago PAL 1, Tokyo, Japan). Titratable acidity (TA, \% malate) was determined by potentiometric titration.

The penetration force was determined using 15 fruits per replication using a TA-XT2i Texture Analyser (Stable Microsystems, Godalming, Surrey, UK), as described [16]. The results were expressed in newtons $(\mathrm{N})$.

\subsubsection{Respiration Activity}

The fruit respiration rate was analysed in three batches of ten fruits per condition (calcium treatment/spurs types/ripening stages). Fruits were enclosed in $2 \mathrm{~L}$ air-tight jars for $30 \mathrm{~min}$ at $20^{\circ} \mathrm{C}$. The respiration rate was assessed using gas chromatography (Shimadzu GC-2014, Kyoto, Japan), as described in detail previously [17].

\subsection{Mineral Elements Analysis in Sweet Cherry Fruit, Buds, and Phloem Tissues}

Determination of nutrients (K, $\mathrm{P}, \mathrm{Ca}, \mathrm{Mg}, \mathrm{Na}, \mathrm{Zn}, \mathrm{Fe}, \mathrm{Mn}, \mathrm{Cu}$ ) was performed in fruits (Table S1), buds, and phloem samples by an inductively coupled plasma optical emission spectrometry (ICP-OES) system (Perkin Elmer Optima 2100DV), using three biological replicates per condition after each tissue incineration at $550{ }^{\circ} \mathrm{C}$ for $6 \mathrm{~h}$ and ash dissolution in $6 \mathrm{~N} \mathrm{HCl} \mathrm{[18].}$

\subsection{Total Phenols, Total Anthocyanins, Flavonols, and Hydroxycinnamic Acids of Sweet Cherries}

The extraction of polyphenolic substances was conducted using 3 biological replicates $\times 10$ fruits per condition, as described [19]. The content of total phenols was determined using the Folin-Ciocalteu method, and optical density was measured at $760 \mathrm{~nm}$ with a microplate reader (Tecan infinite M200 PRO). Results were expressed in equivalents of $\mu \mathrm{g}$ gallic acid g ${ }^{-1} \mathrm{FW}$. 
Total anthocyanins, flavonols, and hydroxycinnamic acids were determined [20] at 520,360 , and $320 \mathrm{~nm}$, respectively, with a UV microplate reader (Tecan infinite M200 PRO). The results were expressed in equivalents of $\mu \mathrm{g}$ cyanidin, rutin, and caffeic acid $\mathrm{g}^{-1} \mathrm{FW}$ for anthocyanins, flavonols, and hydroxycinnamic acids, respectively (Table S2).

\subsection{Primary Polar Metabolite Analysis in Sweet Cherry Skin Tissue}

Primary polar metabolite extraction and derivatization processes were performed as described [21-23] with slight modifications. Frozen ground skin tissue (0.5 gr.) from the control and high $(1 \mathrm{M})$ calcium treatment of black skin colour (full ripe) sweet cherry fruits produced from 1-year-old spurs or 2-year-old spurs were used. Samples were extracted with $1.4 \mathrm{~mL}$ of pure methanol $\left(-20^{\circ} \mathrm{C}\right)$, and adonitol $(0.1 \mathrm{~mL}$ of $1 \mathrm{mg} / \mathrm{mL})$ was added as an internal quantitative standard, then incubated for $10 \mathrm{~min}$ at $70{ }^{\circ} \mathrm{C}$. In

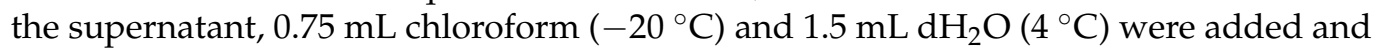
then centrifugated $\left(2200 \times g, 4^{\circ} \mathrm{C}, 10 \mathrm{~min}\right)$. An aliquot of $0.15 \mathrm{~mL}$ of the supernatant was transferred into a glass vial and placed to dry in a desiccator under vacuum. The residues were redissolved in methoxyamine hydrochloride $(0.04 \mathrm{~mL}$ of $20 \mathrm{mg} / \mathrm{mL})$ and then in $\mathrm{N}$-methyl-N-(trimethylsilyl) trifluoroacetamide reagent (MSTFA, $0.07 \mathrm{~mL}$ ) for $120 \mathrm{~min}$ and $30 \mathrm{~min}$ at $37^{\circ} \mathrm{C}$, respectively. The GC-MS analysis was carried out with a Perkin Elmer Clarus ${ }^{\mathrm{TM}}$ SQ 8 (USA) as described in detail [22]. Compounds were determined using standards or the NIST11 database or GOLM metabolome database [24]. The metabolites are expressed as a relative abundance of adonitol, based on the peak area. The description of metabolites and data with relative abundance of metabolites are provided in Table S3.

\subsection{Statistical Processing and Analysis}

The statistical analysis of all quality traits, fruit sets, and mineral elements was conducted using SPSS (SPSS v21.0., Chicago, IL, USA) by 3-way ANOVA or by multivariate analysis of variance (MANOVA) in the analysis of the mineral elements in the two types of tissues (buds and phloem). Metabolic analysis was performed by analysis of variance (ANOVA) between the control and high-dose (1M) $\mathrm{CaCl}_{2}$ treatment. Mean values were compared based on Duncan's multiple range test (more than 2 variables) and Student's $t$-test (for 2 variables and metabolites); $p \leq 0.05$. Specifically, the three factors that were tested in fruit set were the Ca treatments (control, $0.25,0.5$, and $1 \mathrm{M} \mathrm{CaCl}_{2}$ ), the ages of short spurs (1 or 2 years old), and individual tree parameter (tree number 1, 2, 3, or 4). In parallel, the three factors for quality traits and elements were the Ca treatments, ages of spurs ( 1 or 2 years old), and the ripening level (red or black). In the case of cracking estimation procedures (Christensen and Waterfall methods) and fruit water absorption, the statistical analysis was based on Ca treatments, ages of spurs, and the ripening stages.

Principal component analysis (PCA) was used to detect simple patterns, groupings, similarities, and differences. PCA was performed between the control and high-dose (1M) $\mathrm{CaCl}_{2}$ treatment for quality traits and nutrients. The Kaiser-Meyer-Olkin (KMO) measure of sampling adequacy was used for testing whether the variables are adequate to correlate, and Bartlett's test of sphericity (BS) was used for testing if there is a relationship between the variables used. PCs with a variance under $15 \%$ and individual variables with communality or loading under 0.5 were rejected in order to avoid the low representation of variables in the PCA model (Table S4).

\section{Results}

\subsection{Calcium Content in Sweet Cherry Tree Tissues during Dormancy and Its Effect on Fruit Set and Skin Cracking}

In order to examine the internal calcium level in sweet cherry tissues following the external application of calcium $\left(0.25,0.5\right.$, or $\left.1 \mathrm{M} \mathrm{CaCl}_{2}{ }^{*} 2 \mathrm{H}_{2} \mathrm{O}\right)$ during dormancy, phloem, flower, and vegetative buds tissue were analysed for nutrient content one week after the various calcium treatments. Higher calcium content in response to 0.5 and $1 \mathrm{M} \mathrm{CaCl}_{2}$ treatments was detected in phloem and flower buds, but not in vegetative buds (Figure 2). 
Furthermore, calcium content was better explained by the flower bud model $(\mathrm{R} 2=0.74)$ rather than by the phloem model $(\mathrm{R} 2=0.48)$. Moreover, an average increase in the absorption rate by $0.3 \%$ of dry matter per molarity of $\mathrm{CaCl}_{2}$ was defined (Figure 2). With the exception of $\mathrm{P}$ content in flower buds, the levels of the rest of the nutrients $(\mathrm{P}, \mathrm{K}, \mathrm{Mg}$, $\mathrm{Na}, \mathrm{Zn}, \mathrm{Cu}, \mathrm{Mn}, \mathrm{Fe}$ ) were not affected by calcium treatments in the tested tissues (phloem, flower, vegetative buds) (Table S1).

Our data further showed that the fruit set was seriously affected by the individual tree and calcium treatments. An increase of fruit set (\%) was observed in response to 0.25 and $1 \mathrm{M} \mathrm{CaCl}_{2}$ treatments 54 days following sprays ( $40 \mathrm{DAFB}$, Table 1 ), but an even greater effect was found to be tree dependent $(p<0.001)$ or associated with tree $\times$ treatment interaction $(\mathrm{T} \times \mathrm{Tr} ; p<0.01)($ Table 1$)$.

Skin cracking was also affected by the calcium treatments, the age of spurs, and the ripening stages. Lower fruit cracking in the field was observed following 0.5 and $1 \mathrm{M}$ $\mathrm{CaCl}_{2}$ treatments in comparison to the control. In addition, we found lower cracking levels in 2-year-old spurs and in red skin colour cherries than in 1-year-old spurs and black skin colour fruits, respectively (Table 1). Interaction effects between the various calcium treatments and the two ages of spurs as well as between calcium treatments and the two ripening stages were also defined (Table 1). This section may be divided by subheadings. It should provide a concise and precise description of the experimental results, their interpretation, and the experimental conclusions that can be drawn.
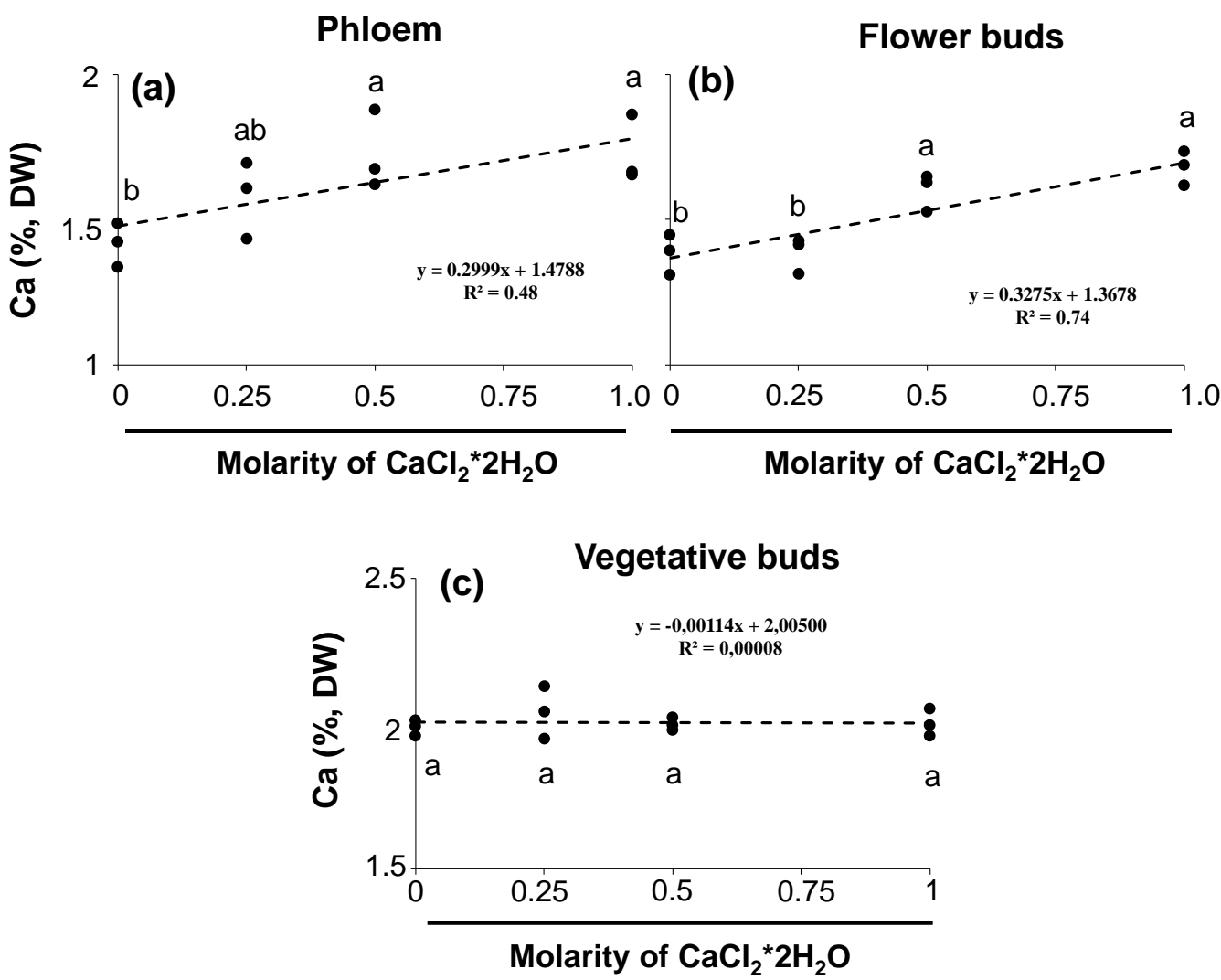

Figure 2. Calcium content from the phloem (a), flower (b), and vegetative buds (c) following 1 week of calcium treatments $\left(0,0.25,0.5\right.$, and $\left.1 \mathrm{M} \mathrm{CaCl}_{2} * 2 \mathrm{H}_{2} \mathrm{O}\right)$. Regression analysis of tissues in response to the different calcium concentration in triplicate per condition. Different letters indicate significant difference based on Duncan's multiple range test, $p \leq 0.05$. 
Table 1. The effect of different factors in fruit set (40 DAFB) and in on-tree fruit cracking at harvest (81 DAFB).

\begin{tabular}{|c|c|c|c|c|c|c|c|}
\hline & & \multicolumn{2}{|c|}{ Fruit Set (\%) } & \multicolumn{4}{|c|}{ On-Tree Fruit Cracking at Harvest (\%) } \\
\hline & & Mean & SD & & & Mean & SD \\
\hline \multirow[t]{4}{*}{ Treatment (T) } & Control & $11.56 \mathrm{a}$ & 6.24 & & & 28.71 a & 8.61 \\
\hline & $\begin{array}{l}0.25 \mathrm{M} \\
\mathrm{CaCl}_{2}\end{array}$ & $16.01 \mathrm{~b}$ & 8.92 & & & $23.84 \mathrm{ab}$ & 11.29 \\
\hline & $\begin{array}{c}0.5 \mathrm{M} \\
\mathrm{CaCl}_{2}\end{array}$ & $14.55 \mathrm{ab}$ & 5.76 & & & $21.18 \mathrm{~b}$ & 5.91 \\
\hline & $\begin{array}{c}1 \mathrm{M} \\
\mathrm{CaCl}_{2}\end{array}$ & $15.09 \mathrm{~b}$ & 4.49 & & & $19.09 \mathrm{~b}$ & 6.04 \\
\hline \multirow{2}{*}{ Age of spurs (AS) } & 1 st & 14.54 & 6.14 & & & 25.86 & 9.07 \\
\hline & 2nd & 14.06 & 7.21 & & & 20.55 & 7.87 \\
\hline \multirow[t]{4}{*}{ Trees (Tr) } & 1 st & $16.91 \mathrm{a}$ & 8.64 & Ripening (R) & Red & 21.48 & 7.29 \\
\hline & 2nd & $16.8 \mathrm{a}$ & 3.82 & & Black & 24.93 & 9.97 \\
\hline & $3 r d$ & $13.23 \mathrm{~b}$ & 5.11 & & & & \\
\hline & 4 th & $10.27 \mathrm{~b}$ & 6.02 & & & & \\
\hline Factors & \multicolumn{2}{|c|}{$p$-value } & $\mathrm{N}$ & Factors & \multicolumn{2}{|c|}{$p$-value } & $\mathrm{N}$ \\
\hline $\mathrm{T}$ & 0.045 & * & 24 & $\mathrm{~T}$ & 0.002 & $* *$ & 16 \\
\hline AS & 0.68 & & 48 & AS & 0.003 & $* *$ & 32 \\
\hline $\operatorname{Tr}$ & $<0.001$ & $* * *$ & 24 & $\mathrm{R}$ & 0.049 & $*$ & 32 \\
\hline $\mathrm{T} \times \mathrm{AS}$ & 0.459 & & 12 & $\mathrm{~T} \times \mathrm{AS}$ & 0.009 & $* *$ & 8 \\
\hline $\mathrm{T} \times \mathrm{Tr}$ & 0.007 & $* *$ & 6 & $\mathrm{~T} \times \mathrm{R}$ & 0.027 & * & 8 \\
\hline $\mathrm{AS} \times \operatorname{Tr}$ & 0.337 & & 12 & $\mathrm{AS} \times \mathrm{R}$ & 0.12 & & 16 \\
\hline $\mathrm{T} \times \mathrm{AS} \times \mathrm{Tr}$ & 0.59 & & 3 & $\mathrm{~T} \times \mathrm{AS} \times \mathrm{R}$ & 0.969 & & 4 \\
\hline
\end{tabular}

Different letters indicate significant difference based on Duncan's multiple range test, $p \leq 0.05$. Asterisks indicate significant difference $\left({ }^{*} p \leq 0.05,{ }^{* *} p \leq 0.01,{ }^{* * *} p \leq 0.001\right)$.

\subsection{The Effect of Calcium Application at Dormancy in the Nutrient Level of Sweet Cherry Fruit at Harvest}

The content of elements in sweet cherry at harvest was significantly altered by calcium treatments, age of spurs, and, particularly, by fruit ripening stage (Tables 2 and S5). Calcium content was higher in red skin colour cherries than in black ones, and the interacting effect of calcium treatment and the ripening stage was also evidenced (Table 2). A lower level of $\mathrm{Zn}$ and $\mathrm{Mn}$ in response to $1 \mathrm{M} \mathrm{CaCl}_{2}$ treatment was detected as well as a decrease of $\mathrm{Cu}$ content in both 0.5 and $1 \mathrm{M} \mathrm{CaCl}_{2}$ treatments in comparison to the control (Table 2). Red skin colour fruits exhibited an accumulation of $\mathrm{Zn}, \mathrm{Mn}, \mathrm{P}, \mathrm{Mg}(p<0.001)$, and $\mathrm{K}(p<0.05)$ compared to the black ones. Additionally, fruits obtained from 2-year-old short spurs showed higher levels of $\mathrm{Mn}$ and $\mathrm{Na}(p<0.05)$ compared to 1-year-old spurs (Table 2 and Table S5). An alternation of $\mathrm{Cu}$ levels has been observed due to the interaction between calcium treatment and the age of short spurs $(p<0.05)$. In addition, $\mathrm{K}$ content was also modified by the interaction between ripening stage and age of short spurs $(p<0.05)$ (Tables 2 and S5).

\subsection{Factors Affecting the Quality Traits of Sweet Cherry Fruits at Harvest}

Sweet cherry quality characteristics at harvest stage were altered by calcium treatments, ages of spurs, and ripening. Total soluble solids (TSS) were higher in the $0.5 \mathrm{M}$ $\mathrm{CaCl}_{2}$ treatment $(p<0.05)$, while titratable acidity (TA) was lower in 0.5 and $1 \mathrm{M} \mathrm{CaCl}_{2}$ treatments $(p<0.001)$ (Table 3). Additionally, TSS was decreased in black skin colour cherries due to the ripening factor $(p<0.05)$. Three interactions among factors that affected TSS were determined. The first interaction was noticed between calcium treatment and the age of spurs $(p<0.05)$, the second between calcium treatment and the ripening stage 
$(p<0.001)$, and the third among calcium treatment, age of spurs, and the ripening stage $(p<0.05)$ (Table 3).

Table 2. The effect of calcium treatments $\left(0,0.25,0.5\right.$, and $\left.1 \mathrm{M} \mathrm{CaCl}_{2} * 2 \mathrm{H}_{2} \mathrm{O}\right)$, ages of short spurs (1and 2-year-old spurs), and the ripening stage (red and black colour fruits) in the $\mathrm{Ca}, \mathrm{Zn}, \mathrm{Cu}$, and $\mathrm{Mn}$ content of fruit.

\begin{tabular}{|c|c|c|c|c|c|c|c|c|c|}
\hline & & \multicolumn{2}{|c|}{$\begin{array}{c}\text { Calcium } \\
\text { (Ca, \% DW) }\end{array}$} & \multicolumn{2}{|c|}{$\begin{array}{c}\text { Zinc } \\
\text { (Zn, ppm) }\end{array}$} & \multicolumn{2}{|c|}{$\begin{array}{c}\text { Copper } \\
(\mathrm{Cu}, \mathrm{ppm})\end{array}$} & \multicolumn{2}{|c|}{$\begin{array}{l}\text { Manganese } \\
\text { (Mn, ppm) }\end{array}$} \\
\hline & & Mean & SD & Mean & SD & Mean & SD & Mean & SD \\
\hline \multirow{4}{*}{ Treatment (T) } & Control & 0.09 & 0.01 & $5.69 \mathrm{a}$ & 0.98 & $4.04 \mathrm{a}$ & 0.5 & $3.26 \mathrm{a}$ & 0.43 \\
\hline & $\begin{array}{l}0.25 \mathrm{M} \\
\mathrm{CaCl}_{2}\end{array}$ & 0.1 & 0.02 & $5.86 \mathrm{a}$ & 1 & 3.7ab & 0.82 & $2.81 \mathrm{~b}$ & 0.42 \\
\hline & $\begin{array}{c}0.5 \mathrm{M} \\
\mathrm{CaCl}_{2}\end{array}$ & 0.1 & 0.01 & $5.32 \mathrm{ab}$ & 0.65 & $3.27 \mathrm{~b}$ & 0.75 & $3.03 \mathrm{ab}$ & 0.49 \\
\hline & $\begin{array}{c}1 \mathrm{M} \\
\mathrm{CaCl}_{2}\end{array}$ & 0.1 & 0.01 & $4.87 \mathrm{~b}$ & 1.09 & $3.2 b$ & 0.69 & $2.98 \mathrm{~b}$ & 0.37 \\
\hline \multirow{2}{*}{$\begin{array}{l}\text { Age of spurs } \\
\text { (AS) }\end{array}$} & $1 \mathrm{st}$ & 0.1 & 0.01 & 5.56 & 1.04 & 3.66 & 0.77 & 2.91 & 0.45 \\
\hline & 2 nd & 0.1 & 0.01 & 5.31 & 0.94 & 3.45 & 0.75 & 3.13 & 0.43 \\
\hline \multirow[t]{2}{*}{ Ripening (R) } & Red & 0.1 & 0.01 & 5.93 & 1 & 3.68 & 0.78 & 3.31 & 0.34 \\
\hline & Black & 0.09 & 0.01 & 4.94 & 0.71 & 3.42 & 0.73 & 2.73 & 0.34 \\
\hline Factors & & $p$-value & $\mathrm{N}$ & $p$-value & $\mathrm{N}$ & $p$-value & $\mathrm{N}$ & $p$-value & $\mathrm{N}$ \\
\hline $\mathrm{T}$ & & 0.263 & 12 & 0.026 & 12 & 0.009 & 12 & 0.013 & 12 \\
\hline AS & & 0.145 & 24 & 0.299 & 24 & 0.266 & 24 & 0.019 & 24 \\
\hline $\mathrm{R}$ & & $<0.001$ & 24 & $<0.001$ & 24 & 0.18 & 24 & $<0.001$ & 24 \\
\hline $\mathrm{T} \times \mathrm{AS}$ & & 0.882 & 6 & 0.67 & 6 & 0.009 & 6 & 0.416 & 6 \\
\hline $\mathrm{T} \times \mathrm{R}$ & & 0.035 & 6 & 0.546 & 6 & 0.677 & 6 & 0.708 & 6 \\
\hline $\mathrm{AS} \times \mathrm{R}$ & & 0.54 & 12 & 0.158 & 12 & 0.464 & 12 & 0.759 & 12 \\
\hline $\mathrm{T} \times \mathrm{AS} \times \mathrm{R}$ & & 0.993 & 3 & 0.426 & 3 & 0.721 & 3 & 0.921 & 3 \\
\hline
\end{tabular}

Different letters indicate significant difference based on Duncan's multiple range test, $p \leq 0.05$.

The cherries after the $0.25 \mathrm{M} \mathrm{CaCl}_{2}$ treatment had the lowest dry matter compared to those treated with 0.5 and $1 \mathrm{M} \mathrm{CaCl}_{2}(p<0.05)$. Moreover, the most striking effect was observed due to the fruit ripening stage $(p<0.001)$, with black skin colour cherries having $1.5 \%$ dry matter higher than the red ones (Table 3 ). Furthermore, the dry matter of sweet cherries was affected $(p<0.05)$ by the interactions between the ripening stage and calcium treatment as well as by the ripening stage and the age of spurs (Table 3). Meanwhile, the respiration rate of fruits was affected by the different calcium applications $(p<0.001)$, ages of spurs $(p<0.001)$, and ripening stages $(p<0.01)$ (Table 3$)$. In particular, respiration activity was increased after calcium treatments as follows: control $<0.25 \mathrm{M}=0.5 \mathrm{M}<1 \mathrm{M}$ $\mathrm{CaCl}_{2}$. Moreover, an increase of fruits' respiratory activity of 2-year-old short spurs and of the red skin colour fruits compared to that of 1-year-old short spurs and of the black skin colour cherries, respectively, was observed (Table 3).

In the remaining quality traits, including skin cracking assessment, flesh portion (\%), and biochemical features at harvest, the most affecting factor was the ripening stage of sweet cherries (Table S2). In detail, the skin cracking index (assessed using Christensen and Waterfall methods) as well as the fruit water absorption (based on the Waterfall method) were significantly affected only by the ripening stage $(p<0.001)$, with the black skin colour cherries exhibiting an increase in the three abovementioned variables. The ratio of the flesh to the whole fruit per fruit was increased in black skin colour cherries $(p<0.05)$ and in the interaction between the ripening stage and age of spur $(p<0.05)$. Furthermore, the effect of the ripening stage on polyphenols $(p<0.05)$, anthocyanins $(p<0.001)$, and 
hydroxycinnamic acid $(p<0.05)$ content was also demonstrated (Table S2). Higher content of polyphenols and anthocyanins was found in black skin colour cherries while the red cherries contained higher levels of hydroxycinnamic acids. In parallel, the penetration force was affected by the age of spurs $(p<0.01)$ and by the ripening stage $(p<0.01)$, with a higher force to be demanded for the penetration of sweet cherries obtained by 1-year-old short spurs and of the red ones (Table S2).

Table 3. The effect of calcium treatments $\left(0,0.25,0.5\right.$, and $\left.1 \mathrm{M} \mathrm{CaCl}_{2} * 2 \mathrm{H}_{2} \mathrm{O}\right)$, ages of short spurs (1- and 2-year-old spurs), and the ripening stage (red and black colour fruits) in the TSS, TA, dry weight, and the respiration rate of the fruits.

\begin{tabular}{|c|c|c|c|c|c|c|c|c|c|}
\hline & & \multicolumn{2}{|c|}{$\begin{array}{c}\text { TSS } \\
(\%, \text { Brix })\end{array}$} & \multicolumn{2}{|c|}{$\begin{array}{c}\text { TA } \\
(\%, \text { Malic Acid })\end{array}$} & \multicolumn{2}{|c|}{$\begin{array}{c}\text { Dry Weight } \\
(\%)\end{array}$} & \multicolumn{2}{|c|}{$\begin{array}{l}\text { Respiration Rate } \\
\left(\mathrm{mL} \mathrm{CO} \mathrm{kg}^{-1} \mathrm{~h}^{-1}\right)\end{array}$} \\
\hline & & Mean & SD & Mean & SD & Mean & SD & Mean & SD \\
\hline \multirow{4}{*}{ Treatment $(\mathrm{T})$} & Control & $15.75 \mathrm{~b}$ & 0.69 & $0.71 \mathrm{a}$ & 0.02 & $15.47 \mathrm{ab}$ & 1.2 & $41.13 \mathrm{c}$ & 3.11 \\
\hline & $\begin{array}{l}0.25 \mathrm{M} \\
\mathrm{CaCl}_{2}\end{array}$ & $15.91 b$ & 0.41 & $0.68 \mathrm{ab}$ & 0.03 & $14.94 \mathrm{~b}$ & 1.85 & $46.62 \mathrm{~b}$ & 2.31 \\
\hline & $\begin{array}{c}0.5 \mathrm{M} \\
\mathrm{CaCl}_{2}\end{array}$ & $16.2 \mathrm{a}$ & 0.33 & $0.65 c$ & 0.03 & 15.99 a & 0.8 & $46.72 \mathrm{~b}$ & 3.1 \\
\hline & $1 \mathrm{M} \mathrm{CaCl}_{2}$ & $15.96 \mathrm{ab}$ & 0.31 & $0.66 \mathrm{bc}$ & 0.04 & $15.68 \mathrm{a}$ & 0.41 & $53.1 \mathrm{a}$ & 2.62 \\
\hline \multirow{2}{*}{ Age of spurs (AS) } & $1 \mathrm{st}$ & 15.95 & 0.56 & 0.68 & 0.04 & 15.67 & 1.35 & 45.11 & 4.95 \\
\hline & 2 nd & 15.95 & 0.38 & 0.67 & 0.03 & 15.37 & 1.07 & 48.67 & 4.62 \\
\hline \multirow[t]{2}{*}{ Ripening (R) } & Red & 16.08 & 0.28 & 0.68 & 0.03 & 14.77 & 1.15 & 47.73 & 4.93 \\
\hline & Black & 15.83 & 0.59 & 0.67 & 0.04 & 16.27 & 0.72 & 46.05 & 5.17 \\
\hline Factors & & $p$-value & $\mathrm{N}$ & $p$-value & $\mathrm{N}$ & $p$-value & $\mathrm{N}$ & $p$-value & $\mathrm{N}$ \\
\hline $\mathrm{T}$ & & 0.022 & 12 & $<0.001$ & 12 & 0.024 & 12 & $<0.001$ & 12 \\
\hline AS & & 1 & 24 & 0.592 & 24 & 0.216 & 24 & $<0.001$ & 24 \\
\hline $\mathrm{R}$ & & 0.014 & 24 & 0.176 & 24 & $<0.001$ & 24 & 0.007 & 24 \\
\hline $\mathrm{T} \times \mathrm{AS}$ & & 0.026 & 6 & 0.115 & 6 & 0.928 & 6 & 0.984 & 6 \\
\hline $\mathrm{T} \times \mathrm{R}$ & & $<0.001$ & 6 & 0.432 & 6 & 0.013 & 6 & 0.393 & 6 \\
\hline $\mathrm{AS} \times \mathrm{R}$ & & 0.127 & 12 & 0.114 & 12 & 0.031 & 12 & 0.449 & 12 \\
\hline $\mathrm{T} \times \mathrm{AS} \times \mathrm{R}$ & & 0.038 & 3 & 0.079 & 3 & 0.289 & 3 & 0.26 & 3 \\
\hline
\end{tabular}

\subsection{PCA Model of Quality Attributes and Nutrient Level of Cherry Fruits Treated with High Dose} of Calcium

The impact of high dose of calcium application $\left(1 \mathrm{M} \mathrm{CaCl}_{2}\right)$ during bud dormancy stage in the sweet cherry quality traits and nutrient content was characterized using PCA analysis. This analysis was performed on the correlation matrix of 24 variables with 9 of them belonging to the mineral elements (Table S4). However, due to the low representation of variables in the PCA model, 14 variables remained, with 6 of them belonging to the nutrients $(\mathrm{P}, \mathrm{Ca}, \mathrm{Mg}, \mathrm{Zn}, \mathrm{Cu}, \mathrm{Mn})$, while the rest of the variables belong to fruit quality traits (i.e., respiration rate, dry weight, anthocyanins, polyphenols, on-tree and in vivo cracking, fruit water absorption) (Figure 3). Total variance of the data explained by the PCA model was $68.5 \%$, with $45.1 \%$ from PC1 and $23.4 \%$ from PC2. Changes in PC1 scores coincide with the dark skin colour, suggesting that PC1 may be associated with ripening. In the structure of PC1, most of the variables (11) are a part of the model construction. Dry weight, anthocyanins, polyphenols, skin cracking (Christensen and Waterfall methods), and fruit water absorption were related to black skin colour cherries, while five of the six nutrients ( $\mathrm{P}, \mathrm{Ca}, \mathrm{Mg}, \mathrm{Mn}, \mathrm{Zn}$ ) were related to red skin colour fruits (Figure 3). On the other hand, PC2 is more closely linked to calcium treatment, and the final construction of PC2 was obtained mainly by three variables with high loadings, which were $\mathrm{Cu}$ content, on-tree cracking, and respiration rate (Figure 3). The $\mathrm{Cu}$ content and on-tree cracking were related 
to a higher level with the control, while the respiration rate was related to a high dose of calcium treatment. Meanwhile, on the biplot of the PCA analysis, a separation between the control and the $1 \mathrm{M} \mathrm{CaCl}_{2}$ treatment, as well as a worthy separation between the black and red skin colour cherries, was clearly observed (Figure 3).

\subsection{Changes in Sweet Cherry Skin Metabolites in Response to High Dose of Calcium Application}

To further characterize the influence of high calcium $\left(1 \mathrm{M} \mathrm{CaCl}_{2}\right)$ treatment in sweet cherry skin metabolism and skin cracking behaviour, primary metabolites in the skin of black (full ripe) sweet cherry fruits obtained from the 1- and the 2-year-old spurs were analysed (Figure 4). This analysis identified 29 skin primary metabolites that were further classified into five categories (Table S3). These metabolic categories correspond to sugars (15 metabolites), alcohols (4 metabolites), acids ( 5 metabolites), amino acids ( 3 metabolites) and other compounds ( 2 metabolites). A lower abundance of ribose was detected in response to the high-dose calcium application in both ages of spurs (Figure 4 and Table S3). Furthermore, the application of high $(1 \mathrm{M})$ calcium decreased oxoproline, arabinose, xylose, and galactose in the skin of the fruit of 1-year-old spurs. On the contrary, an increase of malic acid, rhamnose, quininic acid, maltose, and lactitol was found in cherries of the 1-year-old spurs that were treated with high calcium (Figure 4 and Table S3). Additionally, phosphoric acid and sucrose were increased in the cherries of 2-year-old spurs following the $1 \mathrm{M} \mathrm{CaCl}_{2}$ treatment (Figure 4 and Table S3). Generally, higher levels of acids and other compounds were detected in response to high-calcium application in cherries of 1- and the 2-year-old spurs, respectively (Figure 4 and Table S3).

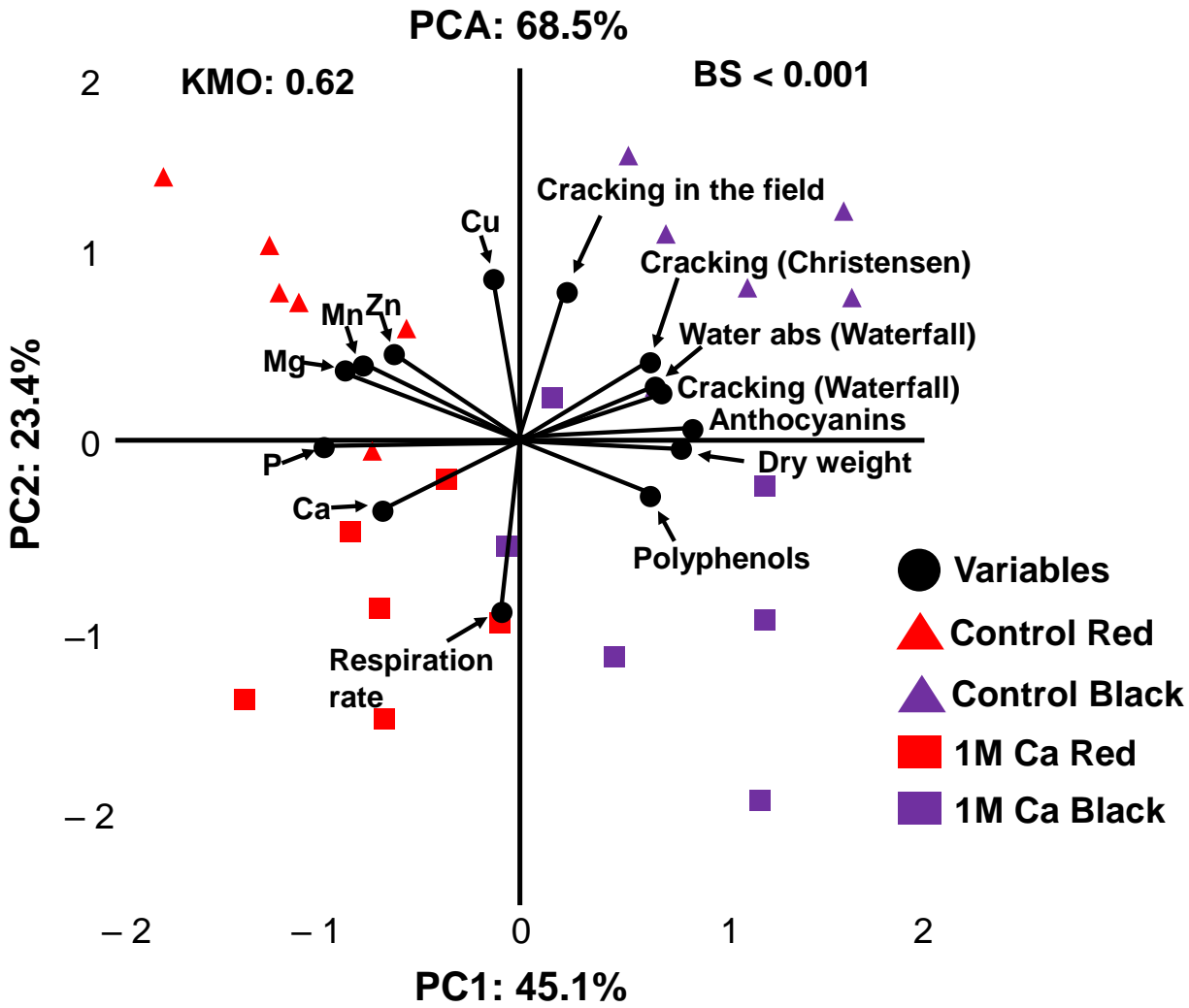

Figure 3. Principal component analysis (PCA) of high-dose calcium $\left(1 \mathrm{M} \mathrm{CaCl}_{2}\right)$ treatment compared to control and red to black skin cherries at harvest. The indicators are Kaiser-Meyer-Olkin (KMO) measure of sampling adequacy and Bartlett's test of sphericity (BS). Control is depicted as triangle and $1 \mathrm{M} \mathrm{CaCl}_{2}$ treatment as square, red skin cherries are depicted in red colour and black skin cherries in purple colour. Variables represented as black circle. 


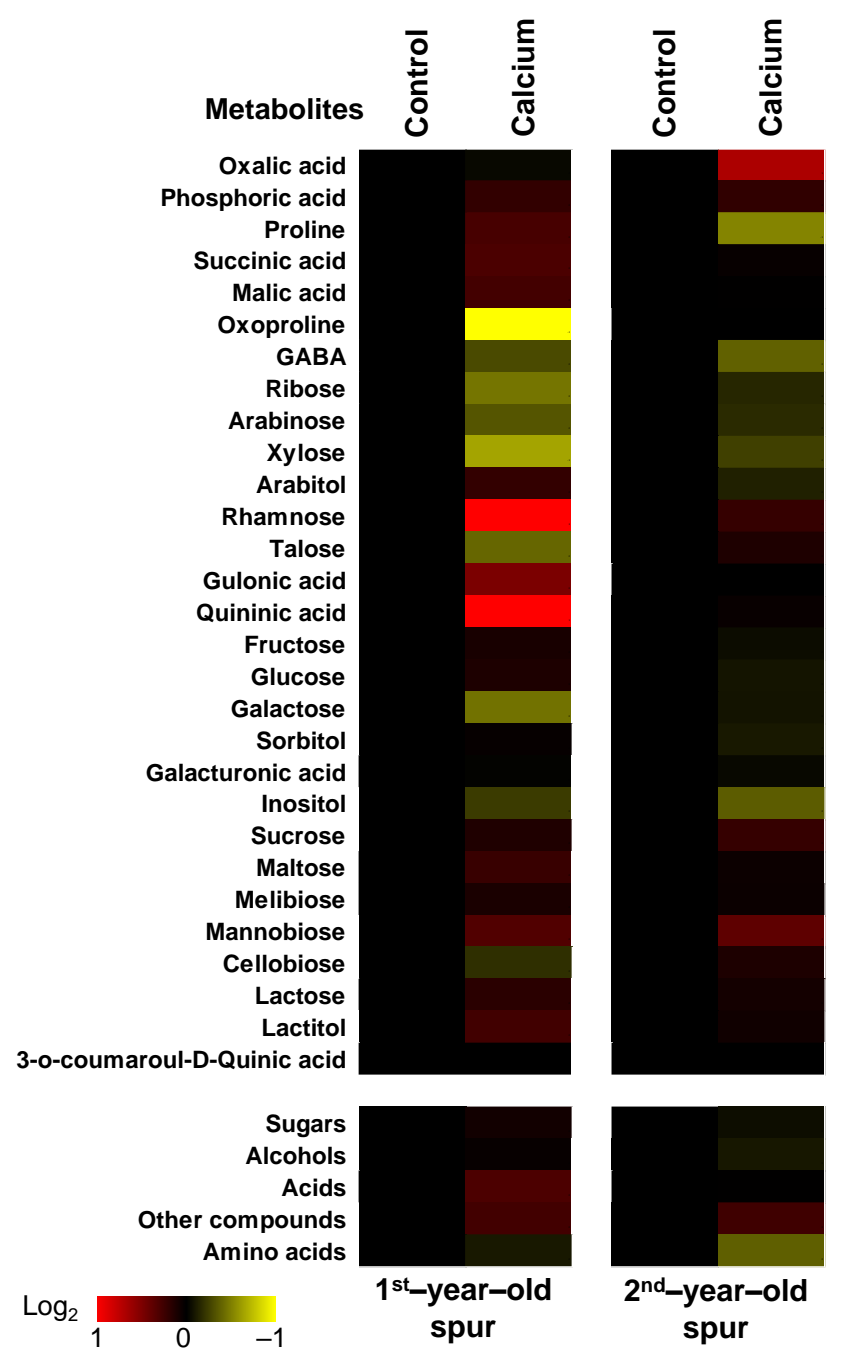

Figure 4. Heatmap diagram of primary polar metabolites in full ripe sweet cherry skin (black skin colour) between control and high-dose calcium $\left(1 \mathrm{M} \mathrm{CaCl}_{2}\right)$ treatment as well as between 1and 2-year-old spurs. The red colour indicates an increase and the green colour a decrease of the metabolite's abundance in response to treatment (1M Ca). Data of metabolite relative abundance are provided in Table S3.

\section{Discussion}

4.1. External Calcium Feeding at Bud Dormancy Altered Nutrient Homeostasis and Ripening Physiology

Recent studies suggested that calcium application via spray during sweet cherry development had a beneficial impact on fruit quality characteristics both at harvest and postharvest periods $[17,25]$. Moreover, foliar applications of high doses of calcium chloride (more than $8 \mathrm{Ca} \mathrm{kg} \mathrm{ha}{ }^{-1}$ ) to fruit trees is not recommended because of potential leaf injury [11]. To overcome this limitation, in this work, we tested the calcium supply via spray in a high dose $\left(0.25,0.5\right.$, and $\left.1 \mathrm{M} \mathrm{CaCl}_{2}\right)$ during the dormant stage (two weeks prior to bud burst) of the sweet cherry tree in the absence of leaves and fruits (Figure 1). In this sense, high doses of mineral element sprays during tree dormant stages, in particular, zinc for nutrient fertilization [12] and copper for preventing the entry of pathogens [13], are well established.

Previous studies proposed that in tissues with lower transpiration rates, such as flower buds and annual shoots, the accumulation of $\mathrm{Ca}^{2+}$ is more difficult because $\mathrm{Ca}^{2+}$ are not translocated at a long distance through the phloem [7]. Current data indicated that one calcium spray in the dormant stage was effective to increase the calcium content in flower 
buds and phloem by $0.3 \%$ (Figure 2). This work further showed that external calcium application during tree dormancy increases endogenous $\mathrm{Ca}^{2+}$ content of red cherries and the $1 \mathrm{M} \mathrm{Ca}$ treatment at harvest (Table 3), indicating that an early bud-load calcium application serves as an efficient system to stimulate calcium accumulation in sweet cherry fruit. Calcium content was gradually increased from dormant to bud break, and then to fully developed leaf due to an increased transpiration rate, resulting in calcium accumulation through xylem transport [18]. It is now known that calcium is relatively immobile in the phloem and in the symplast [8], but phloem is able to provide low concentrations of calcium at a short distance, such as via pedicel to the edible part of sweet cherry. Alternatively, it is possible that several metabolic pathways activated during fruit development, possibly also related to xylem sap transportation, lead to $\mathrm{Ca}^{2+}$ accumulation in cherries (Figure 3). Regarding the content of the rest of the elements, it is interesting to note that fruit copper content was positively associated with skin cracking and negatively with the fruit respiration rate (Figure 3), possibly suggesting an important, still unexplored, role of copper in the sweet cherry physiology.

Significant research into how calcium impacts fruit cell wall interactions and horticultural disorders has been carried out; however, the influence of calcium on fruit ripening has not been thoroughly explored [7]. In this regard, an interesting finding of the present work was the fact that the fruit ripening index (TSS/TA) was increased in ripened sweet cherry as a response to calcium application during tree dormancy (Table 3). This ripening feature is attributed to the higher total soluble solid concentration and simultaneously to the lower titratable acidity of fruits from calcium-treated tree branches (Table 3). However, it remains elusive how an early calcium loading in dormant bud can exert its long-lasting (100 days later) ripening effect in sweet cherry fruit. It was well-documented that abscisic acid (ABA) may play a key role in the regulation of the sweet cherries ripening through the modulation of ripening-related pathways [26]. Additionally, an association between ABA exogenous application and an increase of endogenous calcium content in fruits has been demonstrated [27], which could lead to the hypothesis that the opposite effect, namely the calcium-induced ABA biosynthesis, may occur in order to moderate a possible adverse effect due to the sharp increase of calcium content in the tissue [28], thus leading to the higher ripening index of sweet cherries (Table 3) due to high levels of ABA. An alternative possibility to account for the observed ripening alternation of calcium-treated fruit (Table 3) could liken the $\left[\mathrm{Ca}^{2+}\right]_{\text {cyt }}$ signalling network to a basic cellular 'memory'. There is strong evidence that the $\left[\mathrm{Ca}^{2+}\right]_{\mathrm{cyt}}$ signatures elicited by one environmental challenge can be modified by prior exposure to a contrasting one. For example, the magnitude of the $\left[\mathrm{Ca}^{2+}\right]_{\text {cyt }}$ perturbations in response to oxidative stress was reduced by prior exposure to hyperosmotic stress $[29,30]$, and the magnitude of the $\left[\mathrm{Ca}^{2+}\right]_{\text {cyt }}$ perturbations in response to hyperosmotic stress was reduced by prior exposure to oxidative stress [30,31], suggesting the existence of crosstalk between the memory signalling and the $\left[\mathrm{Ca}^{2+}\right]_{\mathrm{cyt}}$ level responding to these challenges. Similarly, in this work, the short duration of the high-calcium exposure episode might represent a oxidative signal in dormant buds, and possibly also in other sweet cherry tissues, which can be perceived as a 'memory' imprint during the oxidative conditions occurring under the ripening process [32]. Further experiments are needed to clarify the exact biochemical mechanisms underpinning these far-reaching consequences of an early calcium application on sweet cherry ripening physiology.

\subsection{Influence of Sweet Cherry Ripening in Nutrient Status and Quality Traits}

The sweet cherries tree load several days after anthesis includes fruits of different levels of ripening due to the different fruit position on the tree, fruit loading on each branch, fruit shadowing, and other tree training system factors [33]. Apart from calcium-affected quality changes in sweet cherry fruit (Figure 3/Tables 1 and 3), this work revealed several ripening-responsive nutritional changes that occur in fruits with distinct ripening status. For example, calcium, zinc, manganese (Table 2), phosphorus, potassium, and magnesium (Figure 3 and Table S5) were strongly accumulated in red compared to black skin colour 
cherries. Mineral nutrients move into the sweet cherry fruit most rapidly during the early stages of development at a time when xylem water flow dominates [34]. As fruit approach maturity, surface to volume ratio declines, the skin becomes less permeable to water loss, and large amounts of photoassimilate are imported via phloem connections. As a result, a significant part of the nutrients reaching the fruit now through the phloem are loaded into the leaf veins along with the photoassimilate, travel in the phloem, and so reach fruit [35]. Moreover, the xylem of the sweet cherry drupe loses functionality in the course of the last stage (stage III) of development; this decrease is first evident at the stylar (distal) end of the fruit during pit hardening and progresses basipetally towards the pedicel (proximal) end of the fruit at maturity [36]. Such a scenario could be partially explained by the abovementioned accumulation of nutrients in red versus black skin colour fruits (Figure 3).

In the present work, several major quality attributes of sweet cherry fruits were altered in response to ripening (Tables 1 and 3 and Table S5). For instance, skin cracking evaluated at harvest, either on tree or using two in vivo methods, was found to be higher in black skin cherries compared to the red ones (Figure 3). This observation is in line with a previous study that demonstrates a progressive increase of skin cracking with fruit ripening [37]. In addition, other quality traits, such as the levels of anthocyanins and total polyphenols were also higher in the black skin cherries (Figure 3), confirming previous reports [38,39]. Additionally, black skin cherries displayed higher level of dry weight (Figure 3), whereas it had been reported that fruits' dry matter on tree was affected by fruit-loads [40] and the ripening stage [41]. Furthermore, increased skin penetration force has been observed in red skin cherries (Table S2); this quality feature has been mentioned to be related to the harvest stage and fruit canopy position, with a higher force to be demanded in less mature fruits [42].

\subsection{Skin Primary Metabolism and Cracking Development Is Seriously Affected by the Early Calcium Application}

To further evaluate the effect of the high dose of calcium $\left(1 \mathrm{M} \mathrm{CaCl}_{2}\right.$ treatment) on skin primary metabolism and particularly on cracking development, metabolites of sweet cherries of the 1- and the 2-year-old spurs were determined at harvest. Reports on the sweet cherry cracking response have shown that either a foliar or postharvest dipping application of calcium lowered the water-induced cracking [17,25]. An interesting finding that emerged from this work is the fact that skin cracking evaluated in the field was lower following the $1 \mathrm{M} \mathrm{CaCl}_{2}$ treatment (Figure 3). This reduction of on-tree fruit skin cracking could be associated with the Ca-induced respiratory activity (Tables 1 and 3 and Figure 3), which is in line with a previous study indicating that a cracking-tolerant cultivar exhibits higher respiration rates than a highly susceptible to skin cracking cultivar [41].

Emerging evidence suggests that an early metabolic reprogramming occurs in cherry fruit prior to cracking events; however, as of yet, no clear consensus exists on which compounds are linked to cracking development $[14,43,44]$. In line with recent suggestions that the sucrose steady-state level was negatively correlated with cracking development in various sweet cherry cultivars [14], we observed that sucrose abundance was increased by high calcium treatment in fruits obtained from 2-year-old spurs (Figure 4). The accumulation of sucrose in skin tissue plays an osmoregulatory role and would decrease the fruit permeability, thereby allowing less water entry in sweet cherry fruit when exposed to water stress conditions, such as rain-induced cracking [43]. It is also possible that this Ca-elicited sucrose accumulation would provoke the synthesis of carbohydrate polymers, i.e., starch or cellulose, or in the generation of energy necessary for the production of numerous ripening-related compounds [45], thereby altering the ripening physiognomy of sweet cherry fruit. Another interesting observation is the fact that ribose abundance was depressed by calcium treatment in both 1- and 2-year-old spurs (Figure 4), which is in agreement with the induction of ribose levels detected in the skin of the cracking-susceptible cultivar 'Early BiGi' [14], indicating that calcium could regulate skin intracellular energy 
transfer and possibly cracking behaviour by controlling the levels of ribose. Further study on the specific role of sucrose and ribose on calcium action and skin cracking is required.

The decrease of other cell-wall-related sugars in sweet cherry skin, such as arabinose, xylose, and galactose, after the $1 \mathrm{M} \mathrm{CaCl}_{2}$ application on the 1-year-old spurs (Figure 4) is indicative of a possible inactivation of the cell-wall-related enzymes that are associated with cell wall modifications [46]. The current data further disclosed that the application of $1 \mathrm{M}$ $\mathrm{CaCl}_{2}$ provokes the biosynthesis of maltose and quininic acid in the skin tissue. Whether maltose and quininic acid accumulation in Ca-treated fruit may reflect a cracking-related effect is not clear; nevertheless it has been recently mentioned that maltose and quininic were accumulated in cherry flesh and skin tissues due to the high levels of calcium in the fruit tissue [16], highlighting a possible role for these metabolites in the regulation of calcium responses in sweet cherry.

\section{Conclusions}

The evidence discussed presently suggests an important role for early calcium application in sweet cherry fruit physiology that is associated, among other elements, with a specific and long-lasting nutrient, ripening, cracking, and metabolic changes. Furthermore, this work provides insight into sweet cherry quality in terms of ripening status, the age of short spurs, and nutrient accumulation. The data reported here, in combination with previous findings, will expand our understanding of calcium function in sweet cherry and suggest that calcium spray in high doses at the dormant stage represents an efficient approach to improve fruit quality traits at harvest, thereby helping to develop calcium-based treatment strategies for controlling fruit ripening and quality in practice.

Supplementary Materials: The following are available online at https:/ /www.mdpi.com/article /10.3390/horticulturae7060135/s1, Figure S1. Precipitation graph from 15th March until harvest and timeline of foliar sprays, bud burst, and full blossom. Table S1. Quantitative results of mineral elements in phloem, flower, and vegetative buds. Table S2. Quantitative results of sweet cherry quality traits. Table S3. Quantitative results of metabolites in sweet cherry skin. Table S4. PCA extraction variables. Table S5. Quantitative results of nutrients in fruits.

Author Contributions: Conceptualization, M.M. and G.T.; Data curation, M.M., C.P., M.-A.K., D.P.-K., E.K. and A.M.; Formal analysis, M.M., C.P., M.-A.K. and D.P.-K.; Investigation, M.M.; Methodology, M.M.; Project administration, G.T.; Resources, M.M.; Software, M.M.; Supervision, G.T.; Validation, M.M., E.K. and G.T.; Visualization, M.M. and A.M.; Writing-original draft, M.M.; Writing-review and editing, A.M. and G.T. All authors have read and agreed to the published version of the manuscript.

Funding: This research received no external funding.

Acknowledgments: This research did not receive any specific grant from funding agencies in the public, commercial, or not-for-profit sectors.

Conflicts of Interest: The authors declare no conflict of interest.

\section{References}

1. Karagiannis, E.; Sarrou, E.; Michailidis, M.; Tanou, G.; Ganopoulos, I.; Bazakos, C.; Kazantzis, K.; Martens, S.; Xanthopoulou, A.; Molassiotis, A. Fruit quality trait discovery and metabolic profiling in sweet cherry genebank collection in Greece. Food Chem. 2021, 342, 128315. [CrossRef]

2. Ceccarelli, D.; Antonucci, F.; Costa, C.; Talento, C.; Ciccoritti, R. An artificial class modelling approach to identify the most largely diffused cultivars of sweet cherry (Prunus avium L.) in Italy. Food Chem. 2020, 333, 127515. [CrossRef]

3. Pereira, S.; Silva, V.; Bacelar, E.; Guedes, F.; Silva, A.P.; Ribeiro, C.; Gonçalves, B. Cracking in sweet cherry cultivars early bigi and lapins: Correlation with quality attributes. Plants 2020, 9, 1557. [CrossRef]

4. Knoche, M.; Winkler, A. Rain-induced cracking of sweet cherries. In Cherries: Botany, Production and Uses; CABI: Wallingford, UK, 2017; pp. 140-165, ISBN 9781780648378.

5. Winkler, A.; Knoche, M. Calcium and the physiology of sweet cherries: A review. Sci. Hortic. 2019, 245, 107-115. [CrossRef]

6. White, P.J.; Broadley, M.R. Calcium in plants. Ann. Bot. 2003, 92, 487-511. [CrossRef]

7. Hocking, B.; Tyerman, S.D.; Burton, R.A.; Gilliham, M. Fruit Calcium: Transport and Physiology. Front. Plant Sci. 2016,7 , 569. [CrossRef] 
8. Saure, M.C. Calcium translocation to fleshy fruit: Its mechanism and endogenous control. Sci. Hortic. 2005, 105, 65-89. [CrossRef]

9. Arrington, M.; DeVetter, L.W. Foliar applications of calcium and boron do not increase fruit set or yield in northern highbush blueberry (Vaccinium corymbosum). HortScience 2017, 52, 1259-1264. [CrossRef]

10. Crisosto, C.H.; Day, K.R.; Johnson, R.S.; Garner, D. Influence of in-season foliar calcium sprays on fruit quality and surface discoloration incidence of peaches and nectarines. Fruit Var. J. 2000, 54, 118-122.

11. Wojcik, P. "Jonagold" apple fruit quality as influenced by fall sprays with calcium chloride at high rates. J. Plant Nutr. 2001, 24, 1925-1936. [CrossRef]

12. Peryea, F.J. Comparison of dormant and circum-bloom zinc spray programs for washington apple orchards. J. Plant Nutr. 2007, 30, 1903-1920. [CrossRef]

13. Scortichini, M. Field efficacy of a zinc-copper-hydracid of citric acid biocomplex compound to reduce oozing from winter cankers caused by Pseudomonas syringae pv. Actinidiae to Actinidia spp. J. Plant Pathol. 2016, 98, 651-655. [CrossRef]

14. Michailidis, M.; Karagiannis, E.; Tanou, G.; Sarrou, E.; Karamanoli, K.; Lazaridou, A.; Martens, S.; Molassiotis, A. Sweet cherry fruit cracking: Follow-up testing methods and cultivar-metabolic screening. Plant Methods 2020, 16, 1-14. [CrossRef] [PubMed]

15. Christensen, J.V. Cracking in Cherries: III. Determination of Cracking Susceptibility. Acta Agric. Scand. 1972, 22, 128-136. [CrossRef]

16. Michailidis, M.; Karagiannis, E.; Tanou, G.; Sarrou, E.; Stavridou, E.; Ganopoulos, I.; Karamanoli, K.; Madesis, P.; Martens, S.; Molassiotis, A. An integrated metabolomic and gene expression analysis identifies heat and calcium metabolic networks underlying postharvest sweet cherry fruit senescence. Planta 2019, 250, 2009-2022. [CrossRef] [PubMed]

17. Michailidis, M.; Karagiannis, E.; Tanou, G.; Karamanoli, K.; Lazaridou, A.; Matsi, T.; Molassiotis, A. Metabolomic and physicochemical approach unravel dynamic regulation of calcium in sweet cherry fruit physiology. Plant Physiol. Biochem. 2017, 116, 68-79. [CrossRef]

18. Michailidis, M.; Karagiannis, E.; Tanou, G.; Sarrou, E.; Adamakis, I.D.; Karamanoli, K.; Martens, S.; Molassiotis, A. Metabolic mechanisms underpinning vegetative bud dormancy release and shoot development in sweet cherry. Environ. Exp. Bot. 2018, 155, 1-11. [CrossRef]

19. Asami, D.K.; Hong, Y.J.; Barrett, D.M.; Mitchell, A.E. Comparison of the total phenolic and ascorbic acid content of freeze-dried and air-dried marionberry, strawberry, and corn grown using conventional, organic, and sustainable agricultural practices. J. Agric. Food Chem. 2003, 51, 1237-1241. [CrossRef]

20. Obied, H.K.; Allen, M.S.; Bedgood, D.R.; Prenzler, P.D.; Robards, K.; Stockmann, R. Bioactivity and analysis of biophenols recovered from olive mill waste. J. Agric. Food Chem. 2005, 53, 823-837. [CrossRef] [PubMed]

21. Lisec, J.; Schauer, N.; Kopka, J.; Willmitzer, L.; Fernie, A.R. Gas chromatography mass spectrometry-based metabolite profiling in plants. Nat. Protoc. 2006, 1, 387-396. [CrossRef] [PubMed]

22. Michailidis, M.; Karagiannis, E.; Polychroniadou, C.; Tanou, G.; Karamanoli, K.; Molassiotis, A. Metabolic features underlying the response of sweet cherry fruit to postharvest UV-C irradiation. Plant Physiol. Biochem. 2019, 144, 49-57. [CrossRef] [PubMed]

23. Karagiannis, E.; Michailidis, M.; Karamanoli, K.; Lazaridou, A.; Minas, I.S.; Molassiotis, A. Postharvest responses of sweet cherry fruit and stem tissues revealed by metabolomic profiling. Plant Physiol. Biochem. 2018, 127, 478-484. [CrossRef] [PubMed]

24. Hummel, J.; Strehmel, N.; Selbig, J.; Walther, D.; Kopka, J. Decision tree supported substructure prediction of metabolites from GC-MS profiles. Metabolomics 2010, 6, 322-333. [CrossRef] [PubMed]

25. Michailidis, M.; Karagiannis, E.; Tanou, G.; Samiotaki, M.; Tsiolas, G.; Sarrou, E.; Stamatakis, G.; Ganopoulos, I.; Martens, S.; Argiriou, A.; et al. Novel insights into the calcium action in cherry fruit development revealed by high-throughput mapping. Plant Mol. Biol. 2020, 104, 597-614. [CrossRef]

26. Luo, H.; Dai, S.J.; Ren, J.; Zhang, C.X.; Ding, Y.; Li, Z.; Sun, Y.; Ji, K.; Wang, Y.; Li, Q.; et al. The Role of ABA in the Maturation and Postharvest Life of a Nonclimacteric Sweet Cherry Fruit. J. Plant Growth Regul. 2014, 33, 373-383. [CrossRef]

27. Falchi, R.; D'Agostin, E.; Mattiello, A.; Coronica, L.; Spinelli, F.; Costa, G.; Vizzotto, G. ABA regulation of calcium-related genes and bitter pit in apple. Postharvest Biol. Technol. 2017, 132, 1-6. [CrossRef]

28. Martins, V.; Garcia, A.; Costa, C.; Sottomayor, M.; Gerós, H. Calcium- and hormone-driven regulation of secondary metabolism and cell wall enzymes in grape berry cells. J. Plant Physiol. 2018, 231, 57-67. [CrossRef] [PubMed]

29. Knight, H.; Trewavas, A.J.; Knight, M.R. Calcium signalling in Arabidopsis thaliana responding to drought and salinity. Plant J. 1997, 12, 1067-1078. [CrossRef]

30. Knight, H. Calcium signaling during abiotic stress in plants. Int. Rev. Cytol. 1999, 195, 269-324. [CrossRef]

31. Knight, H.; Brandt, S.; Knight, M.R. A history of stress alters drought calcium signalling pathways in Arabidopsis. Plant J. 1998, 16, 681-687. [CrossRef] [PubMed]

32. Tanou, G.; Minas, I.S.; Karagiannis, E.; Tsikou, D.; Audebert, S.; Papadopoulou, K.K.; Molassiotis, A. The impact of sodium nitroprusside and ozone in kiwifruit ripening physiology: A combined gene and protein expression profiling approach. Ann. Bot. 2015, 116, 649-662. [CrossRef] [PubMed]

33. Jajo, A.; Rahim, M.A.; Serra, S.; Gagliardi, F.; Jajo, N.K.; Musacchi, S.; Costa, G.; Bonghi, C.; Trainotti, L. Impact of tree training system, branch type and position in the canopy on the ripening homogeneity of äabbé fétel' pear fruit. Tree Genet. Genomes 2014, 10, 1477-1488. [CrossRef]

34. Brüggenwirth, M.; Winkler, A.; Knoche, M. Xylem, phloem, and transpiration flows in developing sweet cherry fruit. Trees-Struct. Funct. 2016, 30, 1821-1830. [CrossRef] 
35. Brummell, D.S. Fruit growth, ripening and post-harvest physiology. In Plants in Action: Adaptation in Nature, Performance in Cultivation; Atwell, B.J., Kriedemann, P.E., Turnbull, C.G., Eds.; Macmillan Education AU: New York, NY, USA, 1999 ; p. 650.

36. Grimm, E.; Pflugfelder, D.; van Dusschoten, D.; Winkler, A.; Knoche, M. Physical rupture of the xylem in developing sweet cherry fruit causes progressive decline in xylem sap inflow rate. Planta 2017, 246, 659-672. [CrossRef] [PubMed]

37. Christensen, J.V. Cracking in Cherries. VI. Cracking Susceptibility in Relation to the Growth Rhythm of the Fruit. Acta Agric. Scand. 1973, 23, 52-54. [CrossRef]

38. Teribia, N.; Tijero, V.; Munné-Bosch, S. Linking hormonal profiles with variations in sugar and anthocyanin contents during the natural development and ripening of sweet cherries. N. Biotechnol. 2016, 33, 824-833. [CrossRef]

39. Liu, Y.; Shen, X.; Zhao, K.; Ben, Y.; Guo, X.; Zhang, X.; Li, T. Expression Analysis of Anthocyanin Biosynthetic Genes in Different Colored Sweet Cherries (Prunus avium L.) During Fruit Development. J. Plant Growth Regul. 2013, 32, 901-907. [CrossRef]

40. Park, S.J. Dry weight and carbohydrate distribution in different tree parts as affected by various fruit-loads of young persimmon and their effect on new growth in the next season. Sci. Hortic. 2011, 130, 732-736. [CrossRef]

41. Giné-Bordonaba, J.; Echeverria, G.; Ubach, D.; Aguiló-Aguayo, I.; López, M.L.; Larrigaudière, C. Biochemical and physiological changes during fruit development and ripening of two sweet cherry varieties with different levels of cracking tolerance. Plant Physiol. Biochem. 2017, 111, 216-225. [CrossRef]

42. Lewallen, K.S.; Marini, R.P. Relationship between Flesh Firmness and Ground Color in Peach as Influenced by Light and Canopy Position. J. Am. Soc. Hortic. Sci. 2003, 128, 163-170. [CrossRef]

43. Rios, J.C.; Robledo, F.; Schreiber, L.; Zeisler, V.; Lang, E.; Carrasco, B.; Silva, H. Association between the concentration of n-alkanes and tolerance to cracking in commercial varieties of sweet cherry fruits. Sci. Hortic. 2015, 197, 57-65. [CrossRef]

44. Moing, A.; Renaud, C.; Christmann, H.; Fouilhaux, L.; Tauzin, Y.; Zanetto, A.; Gaudillère, M.; Laigret, F.; Claverie, J. Is There a Relation between Changes in Osmolarity of Cherry Fruit Flesh or Skin and Fruit Cracking Susceptibility? J. Am. Soc. Hortic. Sci. 2019, 129, 635-641. [CrossRef]

45. Durán-Soria, S.; Pott, D.M.; Osorio, S.; Vallarino, J.G. Sugar Signaling During Fruit Ripening. Front. Plant Sci. 2020, 11, 1329. [CrossRef] [PubMed]

46. Basanta, M.F.; Ponce, N.M.A.; Salum, M.L.; Raffo, M.D.; Vicente, A.R.; Erra-Balsells, R.; Stortz, C.A. Compositional changes in cell wall polysaccharides from five sweet cherry (Prunus avium L.) cultivars during on-tree ripening. J. Agric. Food Chem. 2014, 62, 12418-12427. [CrossRef] [PubMed] 